\title{
Multivesicular Bodies in Sclerotinia fructigena and their Possible Relation to Extracellular Enzyme Secretion
}

\author{
By F. D. CALONGE* \\ Department of Botany, University of Bristol \\ AND A. H. FIELDING AND R. J. W. BYRDE \\ Long Ashton Research Station, University of Bristol
}

(Accepted for publication I8 September 1968)

\begin{abstract}
SUMMARY
The occurrence of multivesicular bodies (m.v. bodies) in Sclerotinia fructigena, both in vivo and in vitro, was studied by electron microscopy. This investigation was an attempt to correlate the existence of m.v. bodies with extracellular enzyme production. It was observed that when the fungus grew in its natural hosts or in media containing pectin or sodium pectate, where extracellular pectolytic enzyme secretion was high, m.v. bodies were present in the hyphae. However, when the fungus grew in synthetic media without pectin or sodium pectate, these m.v. bodies were absent, and the extracellular enzyme activity was very low. Multivesicular bodies in $S$. fructigena seemed to originate from the endoplasmic reticulum, moving later to the periphery of the cell.

A new histochemical technique was used at the electron microscope level; this provided supporting evidence that m.v. bodies are the cytoplasmic constituents involved in extracellular enzyme secretion by this fungus.
\end{abstract}

\section{INTRODUCTION}

Since the first observation by Girbardt (1958) on vesicular structures associated with the plasmalemma in Polyporus versicolor, several reports have been published on such organelles in different organisms. In 1959, Glauert \& Hopwood described membranous structures in the vicinity of growing cross-walls of bacteria, interpreting them as organelles responsible for cell-wall synthesis. Moore \& McAlear (I96I) reported similar vesicles in other fungi, which they termed 'lomasomes'. Since then, lomasome-like bodies have been described in Botrytis cinerea (Hawker \& Hendy, 1963; Pitt, 1968); in Peronospora manshurica (Peyton \& Bowen, I963); in Albugo candida (Berlin \& Bowen, 1964); in Puccinia graminis tritici (Shaw \& Manocha, 1965) and in Phytophthora infestans and P. parasitica (Ehrlich \& Ehrlich, 1966). Lomasome-like bodies have also been reported in algae (Barton, 1965; Crawley, 1965). Their occurrence in higher plants has been described by Manocha \& Shaw (I964), and reviewed by Esau, Cheadle \& Gill (1966). The latter termed these structures 'boundary bodies', which were always found between plasmalemma and cell wall, but never in the protoplast.

The name 'multivesicular bodies' has been given to certain small vesicles limited by a membrane, itself 50 to $60 \AA$ thick, present in the rat ovum (Sotelo \& Porter, I959).

* Present address: Instituto Botanico 'A. J. Cavanilles' (C.S.I.C.), Madrid I4, Spain. 
Marchant, Peat \& Banbury (1967) postulated multivesicular (m.v.) bodies as structures present in the protoplast, from which lomasomes are formed, and having their origin in the endoplasmic reticulum. However, it is difficult to verify these conclusions from the published micrographs. Structures resembling multivesicular bodies were found in the alga Chlamydomonas reinhardi (Sager \& Palade, 1957) and similar bodies have also been described in higher plants by Walker \& Bisalputra (1967).

In the course of work on the effects of Sclerotinia fructigena on host tissues, it was noticed that multivesicular bodies were present in great numbers in the invading hyphae; this observation encouraged further investigations in vitro on the possible origin and physiological significance of these structures, including an attempt to detect localized enzyme secretion from them.

\section{MATERIALS AND METHODS}

The fungus Sclerotinia fructigena Aderh. \& Ruhl. used for these experiments was isolated by $\mathrm{H}$. J. Willetts from mummified apple fruits collected at Long Ashton Research Station in February 1967.

A monosporic culture was made on potato glucose agar (peeled potato tissue, 200 g.; glucose, 30 g.; agar, 20 g.; to I 1. with distilled water), and maintained either on this medium or on V-8 medium. This comprised V-8 vegetable juice (Campbell's Soups Ltd.), $200 \mathrm{ml}$; agar, $30 \mathrm{~g}$.; to I 1. with distilled water, in large boiling tubes, incubated at $25^{\circ}$.

The in vivo experiments were done by means of inoculations on healthy ripe apple and pear fruits, previously kept in a $25^{\circ}$ incubation room for a few days.

The media used for the in vitro experiments were : (I) Glucose, $0.2 \mathrm{~g}$.; asparagine, $0.2 \mathrm{~g}$; $\mathrm{MgSO}_{4} .7 \mathrm{H}_{2} \mathrm{O}$, 0.075 g.; $\mathrm{K}_{2} \mathrm{HPO}_{4}$, 0.I25 g.; malic acid, 0.5 g.; distilled water to $100 \mathrm{ml}$. and the $\mathrm{pH}$ adjusted to 4.5 by the addition of $\mathrm{N}-\mathrm{NaOH}$. For use as a solid medium, $3 \%$ (w/v) agar was added. (2) The V-8 juice-agar as described above. (3) Apple extract media. Apple fruitlets picked in July (20 g.) were stewed to a pulp with $30 \mathrm{ml}$. distilled water, strained through muslin and the extract made up to $50 \mathrm{ml}$. For use as a solid medium, an equal quantity of $4 \%$ sterilized agar was added after sterilization of the extract. (4) A sodium pectate medium used for pectolytic enzyme production (Byrde \& Fielding, 1968). (5) Pectin (Brown Ribbon brand, Union Crystalex Gelatine Ltd., London) $(2 \%, \mathrm{w} / \mathrm{v})$ in distilled water, without mineral salts. (6) Sodium polypectate (Exchange Lemon Products Co., California) (2\%, w/v) in distilled water, without mineral salts.

The liquid media were dispensed in $4 \mathrm{oz}$. medicine bottles, and the solid media into boiling tubes in $16 \mathrm{ml}$. lots, the tubes being sloped after sterilization.

The inoculum consisted of small mycelial samples from the stock culture.

In all the experiments, both in vivo and in vitro, incubation was at $25^{\circ}$.

\section{Electron microscopy}

Material for ultrastructural studies was collected from infected fruit, 4 days after inoculation; in the in vitro experiments from 2-day-old cultures grown in media I and 3 , from a 7-day-old culture in medium 2, from an II-day-old culture in medium 4 , and from an 8-day-old culture in media 5 and 6. 
In all these cultures the fungus was fully grown when harvested. Samples of mycelia from these sources were fixed by one of the following methods:

(I) 6\% Glutaraldehyde (Sabatini, Bensch \& Barrnett, I963) in $0 . \mathrm{I}$ M-phosphate buffer $\left(\mathrm{pH} 7^{\circ}\right.$ ) for $24 \mathrm{hr}$ at $4^{\circ}$ followed by thorough washing in the same buffer solution, and post-fixed in $2 \% \mathrm{OsO}_{4}$ (in the same buffer) for $4 \mathrm{hr}$ at $4^{\circ}$.

(2) $2 \% \mathrm{KMnO}_{4}$ unbuffered (Luft, 1956), for $30 \mathrm{~min}$. at room temperature, followed by washing in distilled water and staining in $0.5 \%$ aqueous uranyl acetate for 3 days at room temperature (Hess, I966).

The material in both cases was dehydrated in a graded ethanol series and embedded either in Epon 812 or in Araldite mixtures (Luft, I96I). Sections were cut on an LKB Ultratome and stained with lead citrate (Reynolds, 1963); observations were then made with an AEI EM6B electron microscope.

The fixation of the material by the first method was generally better than with $2 \%$ $\mathrm{KMnO}_{4}$. Nevertheless, this second method of fixation gave useful confirmatory information on the distribution of membranes and lipid structures within the cell.

\section{Enzyme estimations}

Polygalacturonase (PG) was estimated at $\mathrm{pH} 4.7$ by the cup-plate assay of Dingle, Reid \& Solomons (1953) with sodium polypectate as substrate. The diameter of the white ring obtained on the agar plate was proportional to the logarithm of enzyme concentration over a range of dilutions. Activities were expressed relative to an aqueous solution (I mg./ml.) of the commercial enzyme Pectinol Io M (Rohm and Haas Ltd.), defined arbitrarily as having 100 units (u.) activity $/ \mathrm{ml}$.

Arabinofuranosidase (AF) and pectin methyl-trans-eliminase (PTE) were estimated at $\mathrm{pH}_{4 \cdot 7}$ and $7 \cdot 0$, respectively, by the methods described by Byrde \& Fielding (1968); these $\mathrm{pH}$ values are approximately optimal.

\section{Histochemical techniques}

An attempt was made to detect localized enzyme secretion by a histochemical method involving the enzyme $\alpha$-L-arabinofuranosidase. This enzyme, known to be secreted by Sclerotinia fructigena in media containing sodium pectate, is suitable because hydrolysis of the phenylglycoside liberates phenol which reacts with a ferric chloride-potassium ferricyanide mixture to give a dark blue electron-dense material.

Fresh samples of mycelium were incubated in an aqueous solution of the substrate, phenyl $\alpha$-L-arabinofuranoside (Börjeson, Jerkeman \& Lindberg, I963; Byrde \& Fielding, 1965), $5 \mathrm{mg}$. $/ \mathrm{ml}$., for various times at room temperature. The material was then thoroughly washed in distilled water, and briefly immersed in a solution containing equal volumes of $\mathrm{I} \%$ potassium ferricyanide and $\mathrm{I} \%$ ferric chloride; a final washing in water was made before fixation for electron microscopy as described above. Control samples were subjected to the same procedure, omitting the initial incubation with phenyl $\alpha$-L-arabinofuranoside.

\section{RESULTS}

Experiments in vivo. When grown on pear fruits, the ultrastructure of hyphae of Sclerotinia fructigena showed numerous multivesicular bodies (m.v. bodies). These bodies were usually located in the vicinity of the cell wall and septum in close associa- 
tion with the plasmalemma (PI. I, fig I, 2) and less frequently inside the protoplast (Pl. I, fig. 3). An observation on such bodies at higher magnification indicated that their internal vesicles are connected to each other and with the plasmalemma by means of thin threads (Pl. 2, fig. 4). These vesicles had an average diameter of 500 to $2000 \AA$ and presented a more or less spherical shape with granular material inside. They were surrounded by a unit membrane about $60 \AA$ thick.

The m.v. bodies were not so numerous when the fungus was grown on apple (P1. 2, fig. 5), but the general appearance of the ultrastructure of the hyphae was similar.

Experiments in vitro. No typical m.v. bodies, as described above, were observed in Sclerotinia fructigena when the fungus was grown on either solid or liquid defined medium, with glucose and asparagine as the sole carbon and nitrogen sources (P1. 2, fig. 6). The hyphal ultrastructure was seen to consist of ribosomes and glycogen with some vacuoles.

No m.v. bodies were observed in Sclerotinia fructigena hyphae grown on V-8 juice agar medium. Plate 3, fig. 7, shows a similar feature to that already described in Pl. I, fig. 2, but while m.v. bodies could clearly be seen close to the septum in the latter, none appeared in the former. Plate 3 , fig. 7 , also shows a nucleus at the moment of crossing the septal pore. The ultrastructure of this material at higher magnification showed some kind of vacuoles with amorphous material, perhaps from abortive m.v. bodies (Pl. 3, fig. 8), and also unusual tubular structures (tubules of about $200 \AA$ diameter) composed of a membrane similar in thickness to the plasmalemma, in which the 'hole' seemed to be of about $70 \AA$ diameter (arrow).

The same material as in Pl. 3, fig. 8, but fixed with permanganate, showed no traces of m.v. bodies (Pl. 3, fig. 9), nor were m.v. bodies observed when Sclerotinia fructigena was grown on potato glucose agar with added apple extract (P1. 3, fig. 10). The ultrastructure of the vegetative hyphae in this case was similar to that presented in P1. 2, fig. 6, when the fungus grew on glucose asparagine medium.

When the fungus was cultured on a medium with sodium pectate, m.v. bodies could be observed (Pl. 4, fig. I I to I4); however, these bodies presented differences in structure and were less numerous than in the hyphae from the in vivo experiments. Plate 4 , fig. I I and I2, also suggest the possible origin of m.v. bodies from the endoplasmic reticulum.

Finally, the ultrastructure of the hyphae maintained in $2 \%$ pectin or sodium pectate alone showed m.v. bodies of similar appearance to those described in the previous case (Pl. 5, fig. 15, 16).

In attempts to elucidate the function of m.v. bodies as possible sources of enzyme secretion, hyphae from medium 4 were examined after treatment by the methods described above. Electron-dense areas appeared to be located in the vicinity of the cell wall, sometimes showing a structure resembling the original m.v. bodies ( $\mathrm{Pl}$. 6, fig. I7), although the general preservation of the cytoplasmic components was not well maintained by this method. Similar deposition of electron-dense material occurred outside the cell wall (P1. 6, fig. I8).

The appearance of control hyphae was markedly different (Pl. 6, fig. 19) showing a few spots only in the cytoplasm but nothing in the proximity of the cell wall.

Table I records the enzyme activities in various media. 
Table 1. Enzyme activity of culture filtrates and formation of multivesicular bodies by $S$. fructigena grown on various media

\begin{tabular}{|c|c|c|c|c|c|}
\hline Source of extract & $\begin{array}{l}\text { PTE } \\
\left(\Delta E_{240} /\right. \\
\text { ml./hr })\end{array}$ & $\begin{array}{l}\text { PG } \\
\text { (u.) }\end{array}$ & $\begin{array}{c}\mathrm{AF} \\
(\Delta \mathrm{A} / \\
\mathrm{ml} . / \mathrm{hr})\end{array}$ & $\begin{array}{c}\mathrm{pH} \\
\text { (after } \\
\text { growth) }\end{array}$ & $\begin{array}{c}\text { M.v. } \\
\text { bodies* }\end{array}$ \\
\hline $\begin{array}{l}\text { Rotted apple tissue (dialysed } \\
5 \% \mathrm{NaCl} \text { extract) } \\
\text { (I ml./g. fresh wt) }\end{array}$ & 0 & 36 & 0.06 & $3 \cdot 8$ & + \\
\hline Medium I liquid & 0 & 4 & 0.04 & $4 \cdot 3$ & - \\
\hline I solid $\dagger$ & 0 & 32 & 0 & $4 \cdot 6$ & - \\
\hline 2 solid $\dagger$ & 0 & 8 & 0.05 & $4 \cdot 8$ & - \\
\hline 3 liquid & 0 & 5 & 0.38 & $3 \cdot 7$ & - \\
\hline 3 solid $†$ & 0 & 0 & 0.12 & $4 \cdot I$ & - \\
\hline 4 liquid & $4 \cdot 05$ & 316 & $2 \cdot 93$ & $7 \cdot 0$ & + \\
\hline 5 liquid $\ddagger$ & 0 & 8 & 0.01 & $3 \cdot 4$ & + \\
\hline 6 liquid & 0 & 128 & 0.19 & 5.0 & + \\
\hline
\end{tabular}

\section{DISCUSSION}

Literature on vesicular structures in plant organisms at present gives a variety of interpretations concerning their possible origin. Wardrop \& Foster (I964) suggested that vesicles, present in the protoplast of epidermal cells of oat coleoptile, seemed to be secreted by the Golgi complex because of their lipid nature. Membranous organelles such as vacuoles and m.v. bodies could be formed by the utilization of stored phospholipids in germinating conidia (Buckley, Sjholm \& Sommer, 1966; Marchant, 1966). The results obtained during this investigation with Sclerotinia fructigena support the evidence that $\mathrm{m}$.v. bodies originate from the endoplasmic reticulum (Pl. 4, fig. I I, I2) as has recently been reported in other fungi (Marchant et al. 1967). Thus it is possible that the m.v. bodies so originated may move towards the cellular periphery by a type of reverse pinocytosis and there empty its content outside the membrane, after fusion with the plasmalemma. This is one of the hypotheses suggested by Lampen (1968) to explain the possible mechanisms of external enzyme formation in yeast.

The views on the physiology of these vesicle-like structures are that they are involved in the synthesis of cell-wall material in the different organisms studied (Glauert \& Hopwood, 1959; Crawley, 1965; Esau et al. 1966; Walker \& Bisalputra, 1967; Marchant et al. 1967). Multivesicular bodies appear to be located, in general, near the plasmalemma and cell wall (Fig. I-5) when they are present in the vegetative hyphae. No traces of m.v. bodies were observed in macro or microconidia of $S$. fructigena (Willetts \& Calonge, 1969).

Apart from their suggested role in cell-wall synthesis, membranous structures in Streptomyces coelicolor (Glauert \& Hopwood, 1959) and tubular organelles in Chara (Barton, I965) are thought to be associated with some specific enzyme activity and they may be sites of extracellular enzyme synthesis in several fungi (Marchant et al. 1967). In Botrytis cinerea, Pitt (1968) demonstrated the location of several acid and neutral hydrolases in cytoplasmic particles by means of histochemical methods. Very recently, 
m.v. bodies have been presumed to be concerned in protein turnover in an insect (Locke \& Collins, 1968) and it has also been shown that the red alga Laurencia can produce a type of vesicle which is able to cross the cell wall (Bisalputra, Rusanowski \& Walker, 1967).

Evidence presented above indicates a similar role for m.v. bodies in Sclerotinia fructigena for the following reasons. If the fungus is grown on certain synthetic media where extracellular PG secretion is very low, the bodies are absent in vegetative hyphae (Pl. 2, fig. 6; P1. 3, fig. 7, 9, I0) and sometimes they appear aborted, or degenerated (Pl. 3, fig. 8). (Pl. 3, fig. 8 also shows the existence of certain tubular structures which could replace the function of the degenerated m.v. bodies). However, when the fungus is grown on host tissue or various pectic media in each of which extracellular PG enzyme secretion is known to occur (Table I) m.v. bodies are present. Apart from anomalous results with autoclaved apple extract a similar pattern emerges for the relationship between AF activity and the presence of m.v. bodies. Moreover, preliminary histochemical examination of such fungal hyphae with the electron microscope gives a positive reaction in bodies which in some cases appear to resemble m.v. bodies. Further histochemical studies seem desirable, using a more specific reagent for the liberated phenol and which at the same time yields an electron-dense product.

One of us (FDC) is grateful to the Fundación Juán March and to the Agricultural Research Council for the award of grants which made this work possible. We also wish to thank Professor L. E. Hawker for her advice and comments during this investigation.

\section{REFERENCES}

Barton, R. (1965). An unusual organelle in the peripheral cytoplasm of Chara cells. Nature, Lond. 205, 201.

BERLN, J. D. \& Bowen, C. C. (1964). The host-parasite interface of Albugo candida on Raphanus sativus. Am. J. Bot. 5I, 445.

Bisalputra, T., Rusanowski, P. C. \& Walker, W. S. (1967). Surface activity, cell wall, and fine structure of pit connection in the red alga Laurencia spectabilis. J. Ultrastruct. Res. $20,277$.

BörJeson, H., JeRKeman, P. \& LindberG, B. (1963). Phenyl glycofuranosides. I. Synthesis of phenyl $\beta$-D-xylofuranoside and phenyl $\alpha$-L-arabinofuranoside. Acta chem. scand. 17, 1705.

Buckley, P. M., SJHolm, E. \& Sommer, N. F. (I966). Electron microscopy of Botrytis cinerea conidia. J. Bact. 9r, 2037.

ByRde, R. J. W. \& Fielding, A. H. (I965). An extracellular $\alpha$-L-arabinofuranosidase secreted by Sclerotinia fructigena. Nature, Lond. 205, 390.

BYRde, R. J. W. \& Fielding, A. H. (1968). Petin methyl-trans-eliminase as the maceration factor of Sclerotinia fructigena and its significance in brown rot of apple. J. gen. Microbiol. 52, 287.

Crawley, J. C. W. (1965). A cytoplasmic organelle associated with the cell walls of Chara and Nitella. Nature, Lond. 205, 200.

Dingle, J., ReID, W. W. \& Solomons, G. L. (1953). The enzymic degradation of pectin and other polysaccharides. II. Application of the 'cup-plate' assay to the estimation of enzymes. J. Sci. Fd Agric. 4, I49.

EHRLICH, M. A. \& EHRLICH, H. G. (I966). Ultrastructure of the hyphae and haustoria of Phytophthora infestans and hyphae of P. parasitica. Can. J. Bot. 44, 1495.

Esau, K., Cheadle, V. I., \& Gill, R. H. (1966). Cytology of differentiating tracheary elements. II. Structures associated with cell surfaces. Am. J. Bot. 53, 765 .

Girbardt, M. (1958). Über die Substruktur von Polystictus versicolor. Arch. Mikrobiol. 28, 255.

Glauert, A. M. \& Hopwood, D. A. (I959). A membraneous component of the cytoplasm in Streptomyces coelicolor. J. biophys. biochem. Cytol. 6, 515 . 
HAWKER, L. E. \& HENDY, R. J. (1963). An electron-microscope study of germination of conidia of Botrytis cinerea. J. gen. Microbiol. 33, 43.

Hess, W. M. (1966). Fixation and staining of fungus hyphae and host plant root tissues for electron microscopy. Stain Technol. 4I, 27.

LAMPEN, J. O. (1968). External enzymes of yeast; their nature and formation. Antonie van Leeuwenhoek 34, 1 .

Locke, M. \& Collins, J. V. (1968). Protein uptake into multivesicular bodies and storage granules in the fat body of an insect. J. Cell Biol. 36, 453 .

LufT, J. H. (1956). Permanganate: a new fixative for electron microscopy. J. biophys, biochem. Cytol. 2, 799.

LUFT, J. H. (1961). Improvements in epoxy resin embedding methods. J. biophys. biochem. Cytol. 9, 409.

MANOCHA, M. S. \& SAAW, M. (1964). Occurrence of lomasomes in mesophyll cells of 'Khapli' wheat. Nature, Lond. 203, 1402.

MaRchaNt, R. (1966). Fine structure and spore germination in Fusarium culmorum. Ann. Bot. 30, $44 \mathrm{I}$.

Marchant, R., Peat, A. \& Banbury, G. H. (1967). The ultrastructural basis of hyphal growth. New Phytol. 66, 623.

MoORE, R. T. \& MCAlear, J. H. (I961). Fine structure of mycota. V. Lomasomes-previously uncharacterised hyphal structures. Mycologia 53, 194.

Peyton, G. A. \& Bowen, C. C. (1963). The host-parasite interface of Peronospora manshurica on Glycine max. Am. J. Bot. 50, 787 .

PITT, D. (1968). Histochemical demonstration of certain hydrolytic enzymes within cytoplasmic particles of Botrytis cinerea Fr. J. gen. Microbiol. 52, 67.

REynolds, E. S. (1963). The use of lead citrate at high $\mathrm{pH}$ as an electron-opaque stain in electron microscopy. J. biophys. biochem. Cytol. r7, 208.

SABatini, D. D., BensCh, K. \& BarRnetT, R. J. (1963). Cytochemistry and electron microscopy. The preservation of cellular ultrastructure and enzymatic activity by aldehyde fixation. $J$. Cell Biol. r7, 19.

SAGer, R., \& PAlade, G. E. (1957). Structure and development of the chloroplast in Chlamydomonas. J. biophys. biochem. Cytol. 3, 463.

SHAW, M. \& MANOCHA, M. S. (1965). The physiology of host-parasite relations. XV. Fine structure in rust-infected wheat leaves. Can. J. Bot. 43, 1285.

Sotelo, J. R. \& PoRTeR, K. R. (1959). An electron-microscope study of the rat ovum. J. biophys. biochem. Cytol. $5,327$.

WALKER, W. S. \& BisalPUTRA, T. (1967). The fine structure of vesicles associated with the cell surface in Helianthus shoot tissue. Can. J. Bot. 45, 2103.

WARDrop, A. B. \& Foster, R. C. (I964). A cytological study of the oat coleoptile. Aust. J. Bot. 12, 135.

Willetts, H. J. \& CAlonge, F. D. (1969). Spore development in the brown rot fungi (Sclerotinia spp.). New Phytol. 67 (in the Press).

\section{EXPLANATION OF PLATES}

Key to symbols: E.R. = endoplasmic reticulum, $\mathrm{H}=$ hypha, H.C. $=$ host cell, $\mathrm{M}=$ mitochondrion, M.V.B. = multivesicular body (or bodies), $\mathrm{N}=$ nucleus, $\mathrm{NU}=$ nucleolus, $\mathrm{P}=$ plasmalemma, $\mathrm{S}=$ septum, $\mathrm{V}=$ vacuole, $\mathrm{VE}=$ vesicle, $\mathrm{W}=$ wall.

\section{Plate I}

Fig. I. Longitudinal section of Sclerotinia fructigena hypha growing in pear. M.V.B. are present (arrows). $\times 9,000$.

Fig. 2. Section showing several M.V.B. in the vicinity of the septum. $\times 20,000$.

Fig. 3. M.V.B. with abundant vesicles filled with a granular material. $\times 120,000$.

\section{Plate 2}

Fig. 4. Multivesicular bodies at higher magnification. The vesicles inside are attached to the plasmalemma (arrows). $\times 100,000$. 
Fig. 5. Part of a hypha of Sclerotinia fructigena growing in apple. Two M.V.B. can be seen among cellular organelles. $\times 20,000$.

Fig. 6. Ultrastructural feature of two hyphae of Sclerotinia fructigena grown in glucose asparagine medium. No M.V.B. can be observed. $\times 34,500$.

\section{Plate 3}

Fig. 7. Longitudinal section of a hypha grown in 'V-8' agar medium. No M.V.B. can be seen (cf. with fig. 2). A nucleus is crossing the septal pore. $\times 15,000$.

Fig. 8. Part of a hypha grown on ' $\mathrm{V}-8$ ' medium. Some tubular structures are present (arrows). There are several vacuoles with an amorphous content with slight resemblance to aborted M.V.B. $\times 90,000$. Fig. 9. The same material as in fig. 8. but fixed with $\mathrm{KMnO}_{4} . \times 20,000$.

Fig. 10. Transverse section of a hypha grown in apple extract liquid medium. M.V.B. are absent. $\times 20,000$.

\section{Plate 4}

Fig. I1. Sclerotinia fructigena hypha grown in a liquid medium with sodium pectate. This cross-section shows some areas of enlarged endoplasmic reticulum with vesicles inside (arrows), resembling those of M.V.B. $\mathrm{KMnO}_{4}$ fixation. $\times 40,000$.

Fig. I2. Section from similar material as in fig. II suggesting the formation of M.V.B. from the endoplasmic reticulum. $\mathrm{KMnO}_{4}$ fixation. $\times 69,000$.

Fig. 13, 14. Different areas from the same material as in fig. I1, and 12, showing several M.V.B. dispersed in the cytoplasm. $\mathrm{KMnO}_{4}$ fixation. Both $\times 60,000$.

\section{Plate 5}

Fig. 15. Section of part of a hypha grown in $2 \%$ pectin in distilled water. An M.V.B. can be seen near the plasmalemma with numerous vesicles inside. $\times 62,500$.

Fig. 16. Longitudinal section of part of a cell at the septum level. An M.V.B. is present near the plasmalemma. $\times 69,000$.

\section{Plate 6}

Fig. 17, 18. Transverse sections of hyphae grown in the sodium pectate medium (no. 4) stained for enzyme detection. The black electron-dense areas, corresponding to the Fe deposition, are located both at the periphery of the cell and outside the wall (arrows). $\times 60,000$ and 45,000 respectively.

Fig. 19. Longitudinal section of a hypha from the same source as in fig. 17 and 18 . (Control). $\times 92,000$. 
Journal of General Microbiology, Vol. 55, No. 2

Plate I
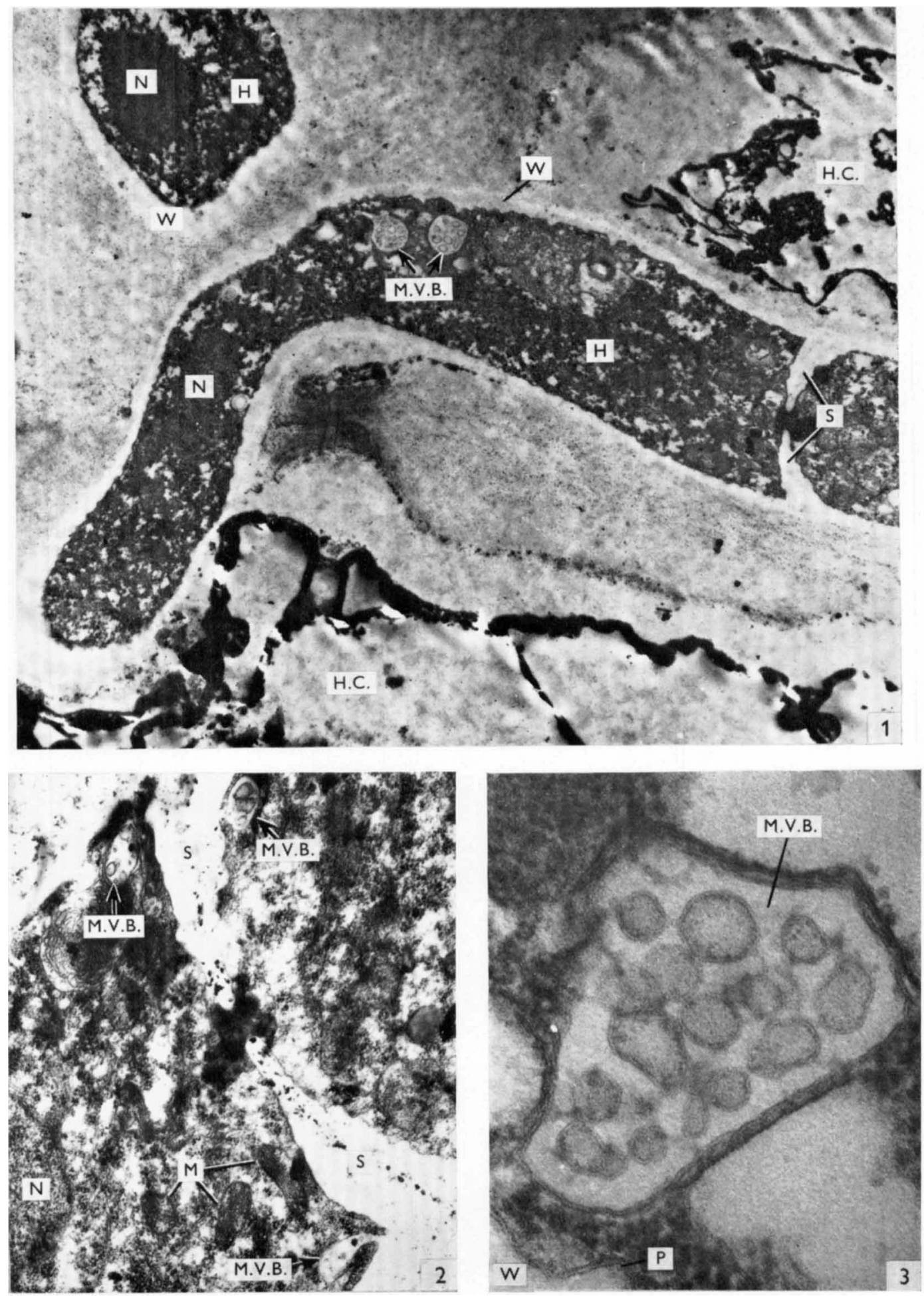

F. D. CAI.ONGE, A. H. FIELDING AND R. J. W. BYRDE

(Facing p. 184) 

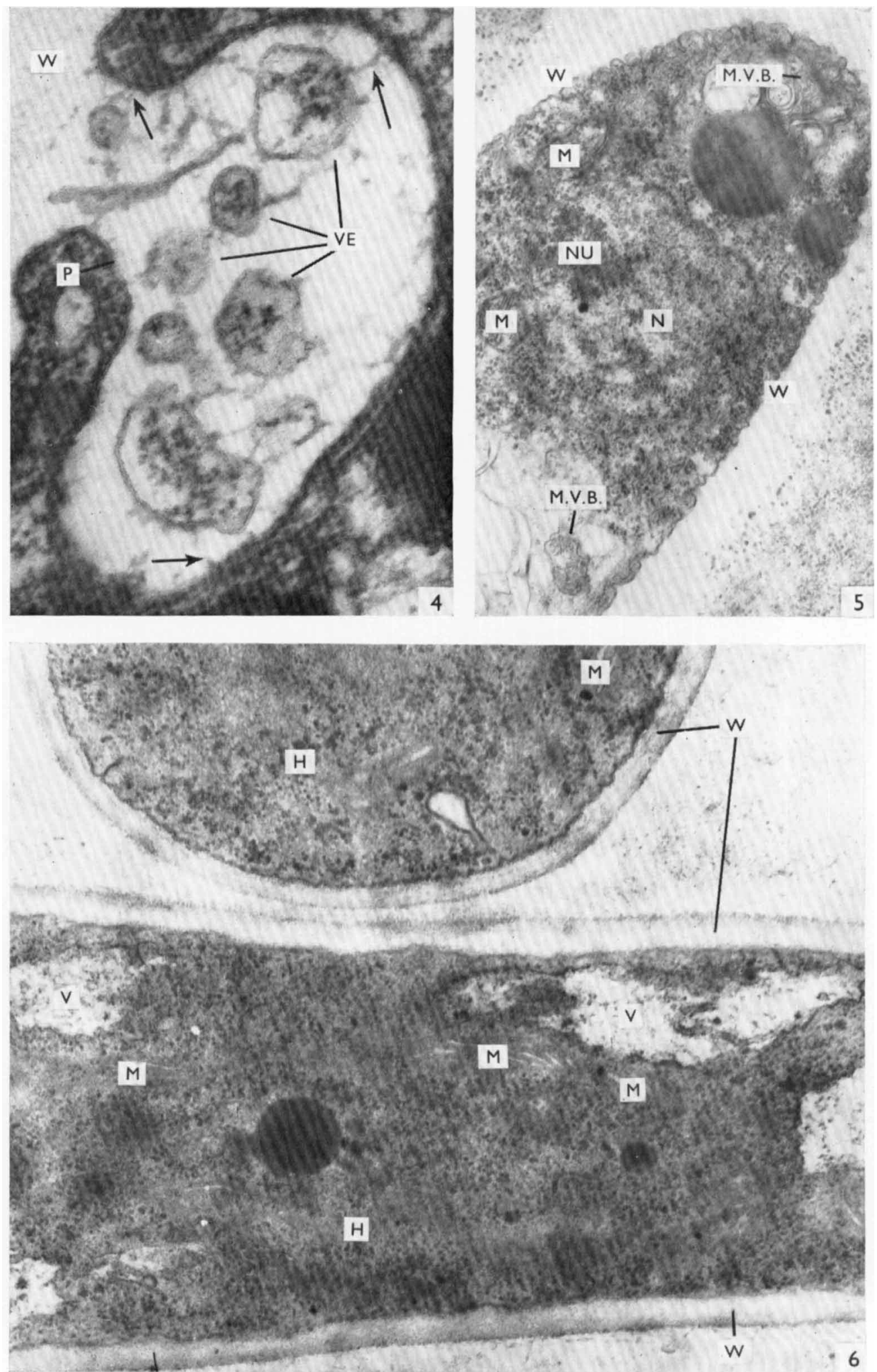
Journal of General Microbiology, Vol. 55, No. 2

Plate 3
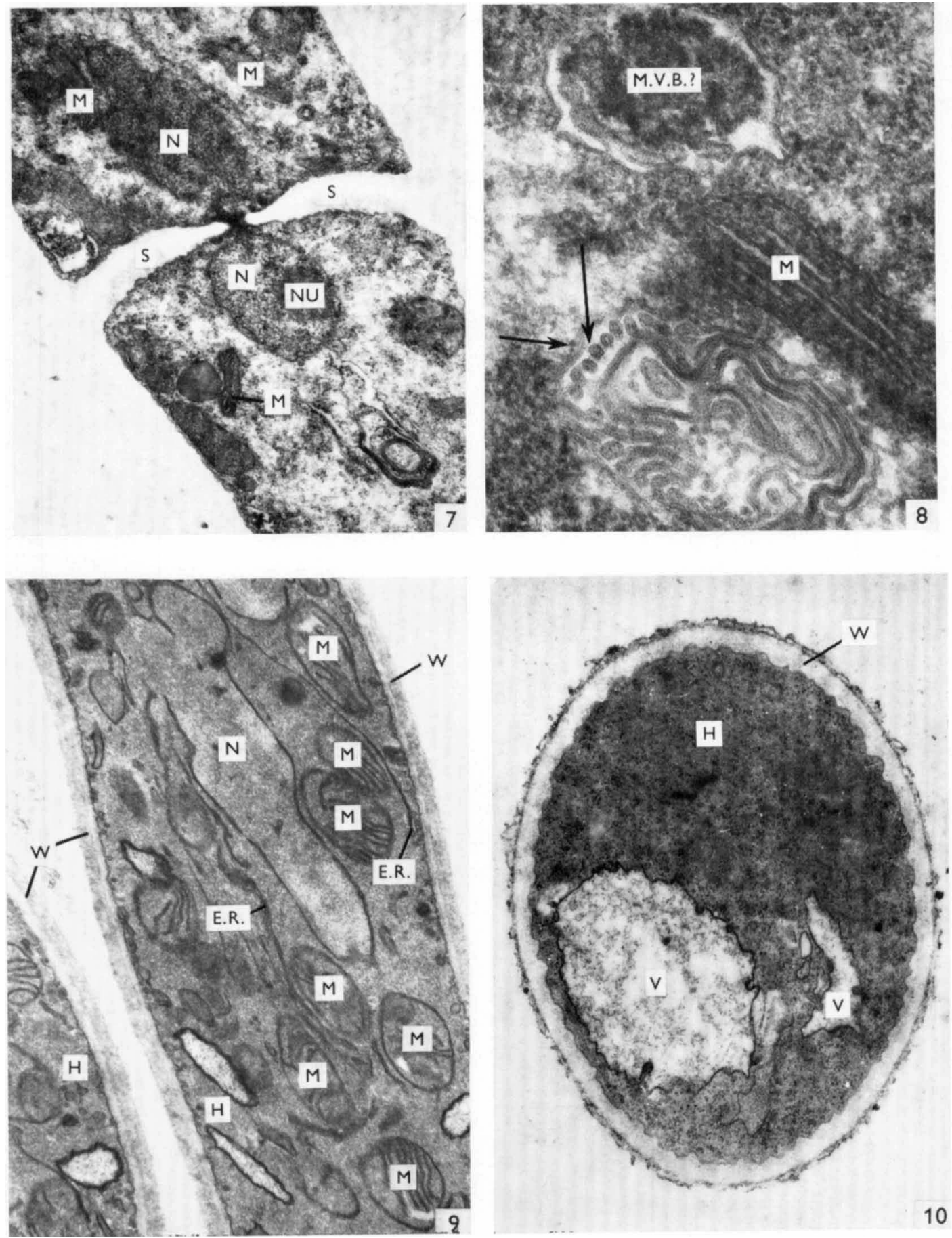

F. D. CALONGE, A. H. FIELDING AND R. J. W. BYRDE 
Journal of General Microbiology, Vol. 55, No. 2

Plate 4
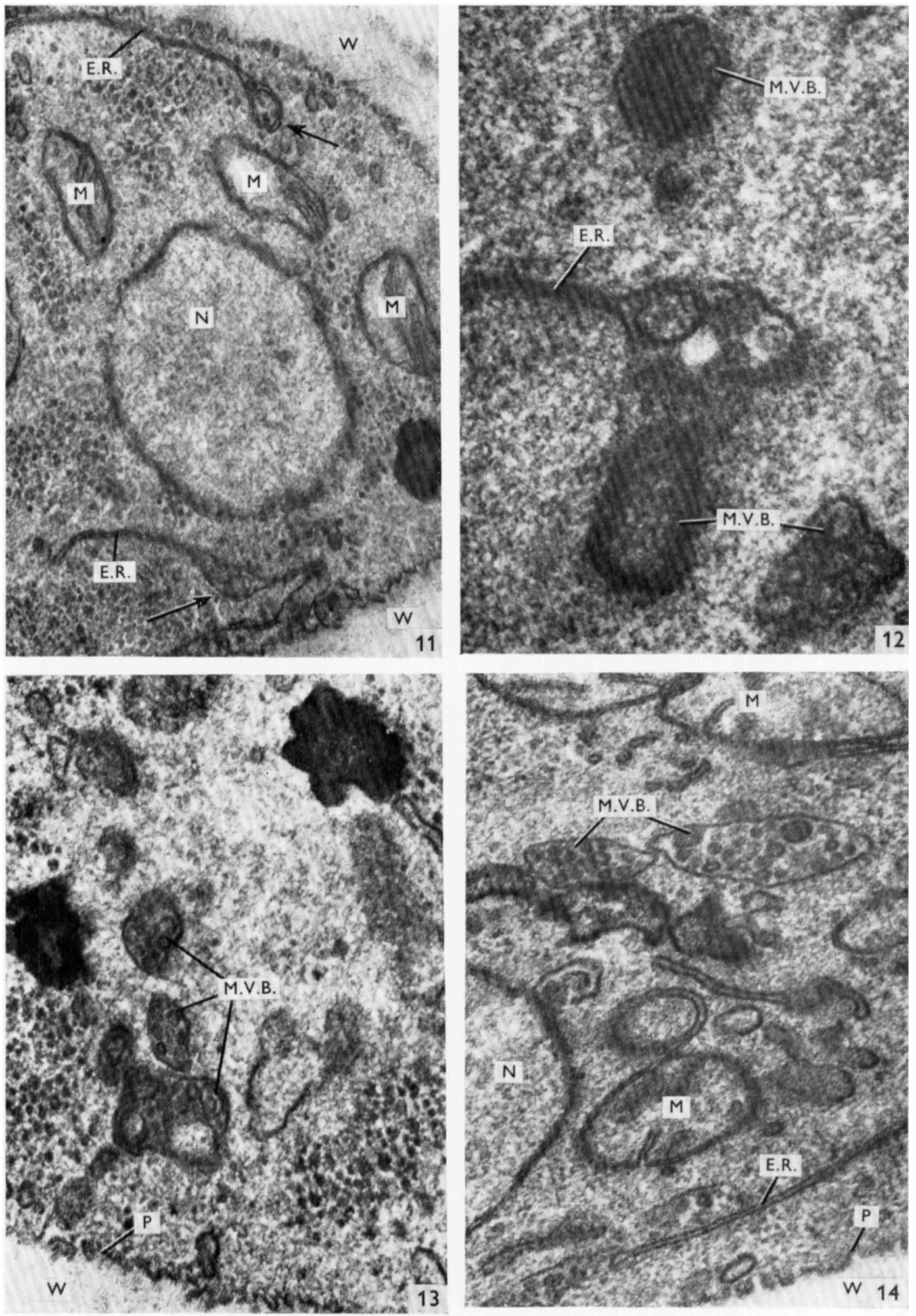

F. D. CALONGE, A. H. FIELDING AND R. J. W. BYRDE 
Journal of General Microbiology, Vol. 55, No. 2

Plate 5
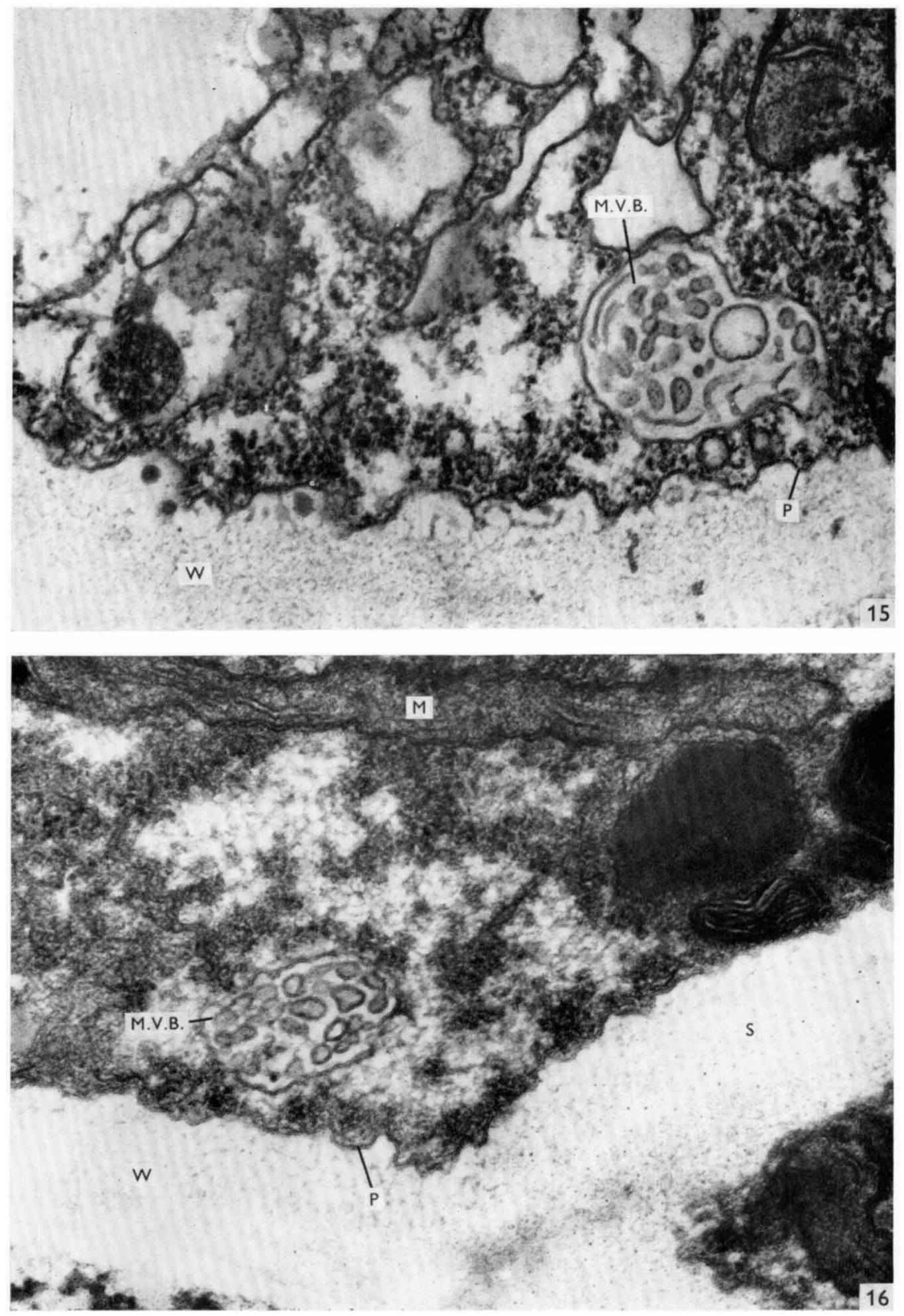

F. D. CALONGE, A. H. FIELDING and R. J. W. BYRDE 
Journal of General Microbiology, Vol. 55, No. 2

Plate 6
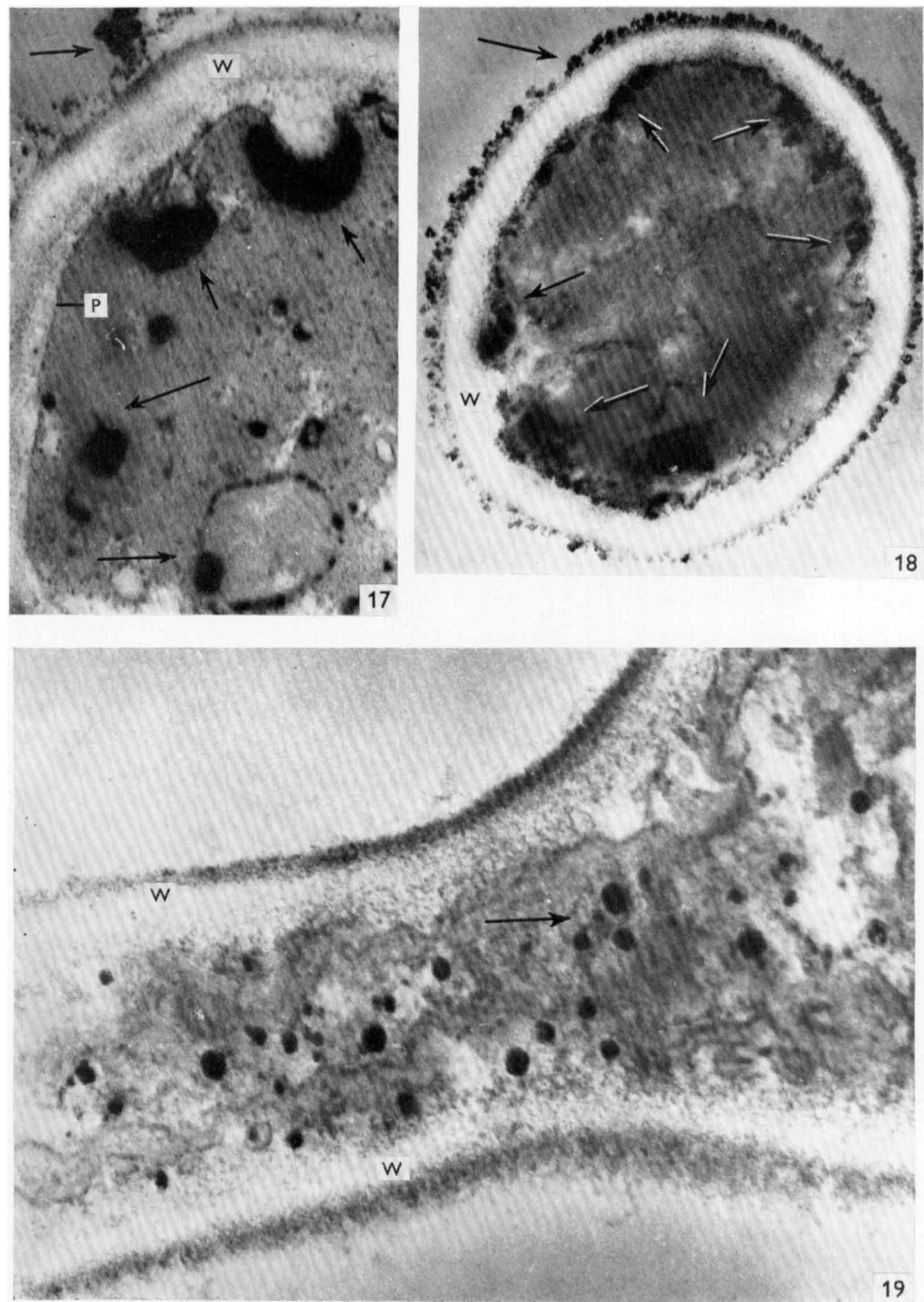

F. D. CALONGE, A. H. FIELDING AND R. J. W. BYRDE 